\title{
Chemoprotective effect of cysteamine against the induction of micronuclei by methyl methanesulfonate and cyclophosphamide
}

\author{
Renato Santos-Mello ${ }^{1}$, Luiz Irineu Deimling ${ }^{2}$, Claudio Lauer Júnior ${ }^{2}$ and Thaís Rieger de Carvalho ${ }^{2}$ \\ ${ }^{1}$ Universidade Luterana do Brasil, Laboratório de Mutagênese, Canoas, RS, Brazil. \\ ${ }^{2}$ Universidade Luterana do Brasil fellow.
}

\begin{abstract}
Cysteamine or 2-mercaptoethylamine (MEA) is an aminothiol with a well-known radioprotective action. No specific information is available in the literature about the possible chemoprotective action of MEA against genotoxic chemical agents. This paper presents the results of studies on the ability of MEA to protect mouse bone marrow polychromatic erythrocytes against the induction of micronuclei by alkylating agents such as methyl methanesulfonate (MMS) and cyclophosphamide (CP). We observed that MEA administered intraperitoneally $30 \mathrm{~min}$ before or $30 \mathrm{~min}$ after the administration of MMS or CP significantly reduced the frequency of micronucleated polychromatic erythrocytes (MNPCEs) induced by the alkylating agents. When MEA was administered in combination with MMS or CP the reduction in the frequency of MNPCEs did not reach statistically significant levels, although it reached values close to significance. With respect to the polychromatic erythrocyte/normochromatic erythrocyte (PCE/NCE) ratio, we observed that MEA did not provide significant protection against the bone marrow toxicity induced by CP.
\end{abstract}

Key words: cysteamine, MEA, micronuclei, amifostine, WR-2721.

Received: December 19, 2003; Accepted: August 4, 2004.

\section{Introduction}

Amifostine or WR-2721 is an organic thiophosphate chemically known as ethanethiol. It was developed during the Cold War as a radioprotectant by the Walter Reed Army Institute-USA (Santini and Giles, 1999). Later studies demonstrated that amifostine selectively protected normal tissue cells in relation to malignant cells both in radiotherapy and chemotherapy, especially when alkylating agents, organoplatinum agents and antracyclins were used (Santini and Giles, 1999; Schuchter, 1997; McCauley, 1997; Foster-Nora and Siden, 1997; Valeriote and Tolen, 1982; List et al., 1996; Murray et al., 2000; Marzatico et al., 2000; De Souza et al., 2000). Mazur and Blawat (1999) observed that amifostine also had a protective effect on mouse bone marrow, significantly reducing the frequencies of micronucleated polychromatic erythrocytes (MNPCEs) induced by cyclophosphamide.

Cysteamine or 2-mercaptoethylamine (MEA) is an aminothiol well known for its radioprotective action (Bacq, 1951). MEA can protect mammalian cells from radiologic phenomena such as cell death (Barendsen, 1964; Eker and

Send correspondence to Renato Santos-Mello. Universidade Luterana do Brasil, Laboratório de Mutagênese, Rua Miguel Tostes 101, Bairro S. Luís, Prédio 19, Sala 208, 92420-280 Canoas, RS, Brazil. E-mail:mello@ulbra.br.
Pihl, 1964; Vergroesen et al., 1967; Sinclair, 1967; 1968; Vos, 1969), mitotic delay (Firket and Mathieu, 1966), chromosome aberrations (Yang and Hahn, 1968; Vos and Kaalen, 1968) and depression of DNA synthesis (Honjo, 1963). Santos-Mello (1977) reported that MEA can also inhibit DNA repair (unscheduled DNA synthesis - UDS) as well as the repair of radioinduced chromosome breaks in human lymphocytes. However, in contrast to amifostine, no specific information is available in the literature about the possible chemoprotective action of MEA against genotoxic chemical agents.

In the present paper, we report the results of studies on the possible chemoprotective action of MEA against the induction of MNPCEs in mice by alkylating agents such as methyl methanesulfonate (MMS) and cyclophosphamide (CP).

\section{Materials and Methods}

The experiments were conducted on bone marrow cells of Swiss albino mice aged 8 to 10 weeks and weighing on average $34 \mathrm{~g}$ (males) and $30 \mathrm{~g}$ (females). The animals were kept in propylene cages, receiving standard ration and water ad libitum, with $52 \%$ humidity and exposed to a $12-\mathrm{h}$ light 12-h darkness photophase at room temperature. 
The experiments with MMS were carried out on females and the experiments with CP on males. All solutions were freshly prepared just before use.

\section{Experiments with MMS and MEA}

The animals were divided into six groups of at least six mice per group and treated as follows: group 1 received only saline solution ( $0.2 \mathrm{~mL} /$ animal - negative control), group 2 received MMS, group 3 received MEA, group 4 received MEA $30 \mathrm{~min}$ before the administration of MMS, group 5 simultaneously received MEA and MMS, and group 6 received MEA $30 \mathrm{~min}$ after the administration of MMS.

MMS (Sigma) and MEA (cysteamine $\mathrm{HCl}$ - Sigma) dissolved in physiological saline were administered intraperitoneally at doses of 50 and $150 \mathrm{mg} / \mathrm{kg}$ body weight, respectively.

\section{Experiments with $\mathrm{CP}$ and MEA}

The animals were also divided into six groups of seven mice per group and treated as described above, except that CP (Genuxal - Asta Medica - $135 \mathrm{mg} / \mathrm{kg}$ body weight) dissolved in physiological saline was administered instead of MMS.

\section{Preparation and scoring}

The animals were sacrificed $24 \mathrm{~h}$ after the respective treatments and slides were prepared by the methods of Heddle (1973) and Schmid (1975). MNPCE frequencies were determined in 2000 polychromatic erythrocytes (PCE)/animal and bone marrow toxicity was determined by the PCE/normochromatic erythrocyte (NCE) ratio in a total of 1000 erythrocytes per animal.

Data were analyzed statistically by the nonparametric Mann-Whitney test (Siegel, 1956) using the BioEstat 2.0 package (Ayres et al., 2000).

\section{Results}

Tables 1 and 2 show the MNPCE frequencies and the percentages of PCE in relation to the total number of erythrocytes in the bone marrow cells of mice submitted to the various treatments.

Table 3 shows the results of statistical comparison of the groups submitted to the different treatments, which demonstrated that:

- Animals treated with MMS or CP alone showed significantly higher MNPCE frequencies than their respective negative controls.

- MNPCE frequencies were significantly higher in the groups treated with MEA alone compared to their respective negative controls, with no significant difference in percent PCE.

- The group treated with MMS alone did not differ significantly from the control group in terms of percent
Table 1 - The effect of MEA on the frequencies of MNPCEs in bone marrow of mice after treatment with MMS

\begin{tabular}{|c|c|c|c|}
\hline Treatment & Animal & $\% \mathrm{PCE}^{\mathrm{a}}$ & $\begin{array}{l}\text { MNPCEs / } \\
1000 \text { PCE }^{b}\end{array}$ \\
\hline \multirow[t]{8}{*}{ Control $^{-}$} & 1 & 52.80 & 2.00 \\
\hline & 2 & 54.60 & 1.50 \\
\hline & 3 & 55.00 & 1.00 \\
\hline & 4 & 52.10 & 2.00 \\
\hline & 5 & 51.50 & 2.50 \\
\hline & 6 & 55.40 & 2.00 \\
\hline & 7 & 55.50 & 2.00 \\
\hline & Mean \pm S.D. & $53.84 \pm 1.67$ & $1.86 \pm 0.48$ \\
\hline \multirow{7}{*}{$\begin{array}{l}\text { MMS } \\
(50 \mathrm{mg} / \mathrm{kg})\end{array}$} & 1 & 48.30 & 25.50 \\
\hline & 2 & 52.00 & 28.00 \\
\hline & 3 & 50.20 & 33.50 \\
\hline & 4 & 54.40 & 21.50 \\
\hline & 5 & 56.60 & 21.50 \\
\hline & 6 & 50.90 & 35.00 \\
\hline & Mean \pm S.D. & $52.07 \pm 3.00$ & $27.50 \pm 5.80$ \\
\hline \multirow{8}{*}{$\begin{array}{l}\text { MEA } \\
(150 \mathrm{mg} / \mathrm{kg})\end{array}$} & 1 & 59.00 & 6.00 \\
\hline & 2 & 53.80 & 4.00 \\
\hline & 3 & 56.40 & 3.00 \\
\hline & 4 & 59.20 & 2.50 \\
\hline & 5 & 56.60 & 2.50 \\
\hline & 6 & 51.20 & 2.50 \\
\hline & 7 & 58.50 & 3.00 \\
\hline & Mean \pm S.D. & $56.39 \pm 2.97$ & $3.36 \pm 1.28$ \\
\hline \multirow{7}{*}{$\begin{array}{l}\text { MMS } \\
(50 \mathrm{mg} / \mathrm{kg})+ \\
\text { MEA } \\
(150 \mathrm{mg} / \mathrm{kg}) \\
(30 \mathrm{~min} \text { before })\end{array}$} & 1 & 53.80 & 20.50 \\
\hline & 2 & 52.20 & 16.50 \\
\hline & 3 & 50.40 & 20.50 \\
\hline & 4 & 49.90 & 26.50 \\
\hline & 5 & 51.00 & 21.00 \\
\hline & 6 & 52.50 & 18.50 \\
\hline & Mean \pm S.D. & $51.63 \pm 1.46$ & $20.58 \pm 3.35$ \\
\hline \multirow{7}{*}{$\begin{array}{l}\text { MMS } \\
(50 \mathrm{mg} / \mathrm{kg})+ \\
\text { MEA } \\
(150 \mathrm{mg} / \mathrm{kg}) \\
\text { (administered } \\
\text { together) }\end{array}$} & 1 & 48.80 & 19.50 \\
\hline & 2 & 54.70 & 18.00 \\
\hline & 3 & 51.30 & 30.50 \\
\hline & 4 & 53.30 & 23.00 \\
\hline & 5 & 54.00 & 19.50 \\
\hline & 6 & 48.30 & 21.00 \\
\hline & Mean \pm S.D. & $51.73 \pm 2.72$ & $21.92 \pm 4.53$ \\
\hline \multirow{8}{*}{$\begin{array}{l}\text { MMS } \\
(50 \mathrm{mg} / \mathrm{kg})+ \\
\text { MEA } \\
(150 \mathrm{mg} / \mathrm{kg}) \\
(30 \mathrm{~min} \text { after })\end{array}$} & 1 & 44.00 & 12.00 \\
\hline & 2 & 45.50 & 13.50 \\
\hline & 3 & 53.10 & 9.00 \\
\hline & 4 & 51.80 & 12.50 \\
\hline & 5 & 47.50 & 17.50 \\
\hline & 6 & 51.80 & 14.50 \\
\hline & 7 & 55.10 & 20.00 \\
\hline & Mean \pm S.D. & $49.83 \pm 4.01$ & $14.14 \pm 3.65$ \\
\hline
\end{tabular}

${ }^{\mathrm{a}} 1000$ erythrocytes/sample were scored. ${ }^{\text {b2 }} 2000$ PCEs/sample were scored. 
Table 2 - The effect of mea on the frequencies of MNPCEs in bone marrow of mice after treatment with $\mathrm{CP}$.

\begin{tabular}{|c|c|c|c|}
\hline Treatment & Animal & $\% \mathrm{PCE}^{\mathrm{a}}$ & $\begin{array}{l}\text { MNPCEs / } \\
1000 \text { PCE }^{\mathrm{b}}\end{array}$ \\
\hline \multirow[t]{8}{*}{ Control $^{-}$} & 1 & 48.90 & 2.00 \\
\hline & 2 & 49.90 & 4.00 \\
\hline & 3 & 57.90 & 3.50 \\
\hline & 4 & 57.60 & 2.50 \\
\hline & 5 & 56.00 & 2.00 \\
\hline & 6 & 55.00 & 3.00 \\
\hline & 7 & 56.20 & 2.50 \\
\hline & Mean \pm S.D. & $54.50 \pm 3.63$ & $2.79 \pm 0.76$ \\
\hline \multirow{8}{*}{$\begin{array}{l}\text { CP } \\
(135 \mathrm{mg} / \mathrm{kg})\end{array}$} & 1 & 35.90 & 19.50 \\
\hline & 2 & 43.50 & 21.00 \\
\hline & 3 & 38.90 & 23.50 \\
\hline & 4 & 37.60 & 25.50 \\
\hline & 5 & 33.70 & 18.50 \\
\hline & 6 & 33.80 & 17.00 \\
\hline & 7 & 47.70 & 20.00 \\
\hline & Mean \pm S.D. & $38.73 \pm 5.20$ & $20.71 \pm 2.93$ \\
\hline \multirow{8}{*}{$\begin{array}{l}\text { MEA } \\
(150 \mathrm{mg} / \mathrm{kg})\end{array}$} & 1 & 51.00 & 3.00 \\
\hline & 2 & 56.10 & 3.00 \\
\hline & 3 & 54.50 & 4.50 \\
\hline & 4 & 58.40 & 4.50 \\
\hline & 5 & 54.20 & 3.50 \\
\hline & 6 & 57.70 & 4.50 \\
\hline & 7 & 60.50 & 5.50 \\
\hline & Mean \pm S.D. & $56.06 \pm 3.15$ & $4.07 \pm 0.93$ \\
\hline \multirow{8}{*}{$\begin{array}{l}\mathrm{CP} \\
(135 \mathrm{mg} / \mathrm{kg})+ \\
\mathrm{MEA} \\
(150 \mathrm{mg} / \mathrm{kg}) \\
(30 \mathrm{~min} \text { before })\end{array}$} & 1 & 38.30 & 17.50 \\
\hline & 2 & 40.40 & 12.00 \\
\hline & 3 & 42.60 & 12.50 \\
\hline & 4 & 49.80 & 8.50 \\
\hline & 5 & 40.80 & 16.00 \\
\hline & 6 & 45.50 & 16.00 \\
\hline & 7 & 43.20 & 12.00 \\
\hline & Mean \pm S.D. & $42.94 \pm 3.79$ & $13.50 \pm 3.14$ \\
\hline \multirow{8}{*}{$\begin{array}{l}\mathrm{CP} \\
(135 \mathrm{mg} / \mathrm{kg})+ \\
\text { MEA } \\
(150 \mathrm{mg} / \mathrm{kg}) \\
\text { (administered in } \\
\text { combination) }\end{array}$} & 1 & 40.70 & 17.50 \\
\hline & 2 & 35.60 & 18.00 \\
\hline & 3 & 35.00 & 12.50 \\
\hline & 4 & 34.20 & 20.00 \\
\hline & 5 & 35.20 & 9.50 \\
\hline & 6 & 40.00 & 19.50 \\
\hline & 7 & 37.00 & 20.00 \\
\hline & Mean \pm S.D. & $36.81 \pm 2.56$ & $16.71 \pm 4.11$ \\
\hline \multirow{8}{*}{$\begin{array}{l}\text { CP } \\
(135 \mathrm{mg} / \mathrm{kg})+ \\
\text { MEA } \\
(150 \mathrm{mg} / \mathrm{kg}) \\
(30 \mathrm{~min} \text { after })\end{array}$} & 1 & 35.40 & 12.50 \\
\hline & 2 & 34.50 & 11.50 \\
\hline & 3 & 43.50 & 12.00 \\
\hline & 4 & 43.10 & 8.50 \\
\hline & 5 & 42.60 & 8.50 \\
\hline & 6 & 39.40 & 9.50 \\
\hline & 7 & 39.20 & 16.00 \\
\hline & Mean \pm S.D. & $39.67 \pm 3.66$ & $11.21 \pm 2.67$ \\
\hline
\end{tabular}

${ }^{a} 1000$ erythrocytes/sample were scored.

b2000 PCEs/sample were scored.
PCE, indicating that the dose used was not toxic to bone marrow.

- The group treated with $\mathrm{CP}$ alone showed a significantly lower percentage of PCE compared to the negative control, indicating toxicity to bone marrow.

- When MEA was administered to the animals $30 \mathrm{~min}$ before or 30 min after MMS or CP, MNPCE frequencies were significantly reduced compared to the animals treated with MMS or CP alone.

- When MEA was administered to the mice together with MMS or CP there was a reduction in MNPCE frequency which was close to significance although it did not reach it.

- The maximum reduction in MNPCE frequency occurred when MEA was administered 30 min after MMS or CP.

- At the dose used, MEA did not confer significant protection in terms of toxicity to bone marrow (measured as $\%$ PCE), although it showed a chemoprotective action against the induction of MNPCEs caused by CP.

\section{Discussion}

The present results demonstrated that MEA can protect mouse bone marrow PCE against MNPCE induction by alkylating agents such as MMS and CP.

Alkylating agents can bind DNA, causing damage that may result in strand breaks, chromosome breaks, micronucleus formation, and cell death (Mazur and Blawat, 1999; Brookes, 1990; Moore, 1991). The extent of DNA damage induced by alkylating agents depends on thiol concentration in the cell nucleus (Moore, 1991). The protective mechanisms of thiols are not fully known but probably include free radical scavenging, hydrogen donation reactions, and inhibition of alkylating agents when the thiol attracts the positively charged carbonium ions (Mazur and Blawat, 1999). We found no information in the literature about the specific chemoprotective action of MEA against genotoxic chemical products such as alkylating agents. We suggest that the chemoprotection observed here for MEA was due to radical scavenging and hydrogen donation reactions, as reported for the chemoprotective agent WR-1065, the active metabolite of amifostine (Spencer and Goa, 1995).

Mazur and Blawat (1999), reported that amifostine significantly reduced MNPCE frequencies in PCE even when administered half an hour before CP. Spencer and Goa (1995), reported cell protection when amifostine was administered up to one hour after $\mathrm{CP}$ therapy. With respect to MEA, we observed a significant reduction in MNPCE frequency even when this aminothiol was administered $30 \mathrm{~min}$ before or $30 \mathrm{~min}$ after the alkylating agents.

Indeed, amifostine is a pro-drug which is rapidly dephosphorylated by a cell membrane enzyme (alkaline phosphatase) resulting in an active form denoted WR-1065. So far, chemoprotection against alkylating agents has been mainly attributed to WR-1065 (Santini and Giles, 1999; 
Table 3 - Comparison of the various samples by the Mann-Whitney test.

\begin{tabular}{|c|c|c|c|c|c|c|}
\hline & \multicolumn{3}{|c|}{ PCE } & \multicolumn{3}{|c|}{ Micronuclei } \\
\hline & $\mathrm{U}^{\mathrm{b}}$ & $\mathrm{Z}$ & $\mathrm{P}$ & $\mathrm{U}^{\mathrm{b}}$ & Z & $\mathrm{P}$ \\
\hline Control' $^{-} \mathrm{X}$ MMS & 11.0 & 1.429 & 0.153 & 0.0 & 3.000 & $0.003^{\mathrm{a}}$ \\
\hline Control $^{-} \mathrm{X}$ MEA & 11.0 & 1.725 & 0.084 & 1.5 & 2.939 & $0.003^{\mathrm{a}}$ \\
\hline MMS X MMS + MEA (administered 30 min before) & 18.0 & 0.000 & $>0.999$ & 3.0 & 2.401 & $0.016^{\mathrm{a}}$ \\
\hline MMS X MMS + MEA (administered in combination) & 17.5 & 0.080 & 0.936 & 6.0 & 1.921 & 0.055 \\
\hline MMS X MMS + MEA (administered 30 min after) & 15.0 & 0.857 & 0.391 & 0.0 & 3.000 & $0.003^{\mathrm{a}}$ \\
\hline Control $^{-} \mathrm{X} \mathrm{CP}$ & 0.0 & 3.130 & $0.002^{\mathrm{a}}$ & 0.0 & 3.130 & $0.002^{\mathrm{a}}$ \\
\hline Control $^{-} \mathrm{X}$ MEA & 19.0 & 0.703 & 0.482 & 6.5 & 2.300 & $0.021^{\mathrm{a}}$ \\
\hline CP X CP + MEA (administered 30 min before) & 12.0 & 1.597 & 0.110 & 1.0 & 3.003 & $0.003^{\mathrm{a}}$ \\
\hline CP X CP + MEA (administered in combination) & 21.0 & 0.447 & 0.655 & 11.5 & 1.661 & 0.097 \\
\hline
\end{tabular}

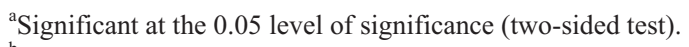

${ }^{\mathrm{b}} \mathrm{U}$, Mann-Whitney U test.

Spencer and Goa, 1995; Shaw et al., 1996). Considering the fact that WR-1065, in turn, can also be metabolized to MEA and others sulphide compounds with reactive sulphydryl groups (Mazur and Blawat, 1999; Spencer and Goa, 1995; Shaw et al., 1996) and on the basis of the present findings, we cannot rule out the possibility that at least part of the chemoprotective action attributed to WR-1065 may be actually due to the action of MEA.

Our results also demonstrate that, even though MEA presented a chemoprotective action in terms of micronucleus induction by MMS and $\mathrm{CP}$, it can produce, on its own, a significant increase in micronuclei compared to the negative control, as previously reported by Mazur (1995). However, this investigator can not explain the reason for these findings. Delrez and Firket (1968) observed that MEA at low concentrations was able to induce chromosome breaks in Chinese hamster cells. Takagy et al. (1974), in experiments conducted on Hela cells observed that the genotoxicity of MEA at low concentrations developed gradually over time during which hydrogen peroxide was generated in the medium, with the addition of catalase and peroxidase inhibiting this "paradoxical" effect. Vergroesen et al. (1967), demonstrated that thiols with a pK value of less than 10 were toxic at concentrations of 0.1 and $2.0 \mathrm{mM}$, with the addition of another thiol at high concentrations, the lowering of the $\mathrm{pH}$ or the presence of $\mathrm{KCN}$ (which has no radioprotective power and has no effect on the radioprotective action of $\mathrm{SH}$ compounds), eliminating the toxicity. Whereas the addition of $\mathrm{Na}_{2} \mathrm{~S}_{2} \mathrm{O}_{3}$ (which does not penetrate the cell) to the system does not change the toxic condition, a fact probably indicating that this toxicity may be due to a process occurring at the intracellular level, possibly of an oxidative nature. To explain the toxicity of cysteamine, the same authors proposed that, at low concentrations, this compound dissociates into thiol ions (RS-) and $\mathrm{H}+$ ions (at a pK value of 8.3 ) and that its toxicity may be due to the presence of thiol ions. For the case described in the present paper, cysteamine administered i.p. to mice appears to be eliminated gradually until its concentration is so low that it reaches a point when it favors the triggering of the reaction described above. Finally, we suggest that further studies are needed to establish the most effective MEA dose and time of administration for chemoprotection, since in the present study we only administered one dose (150 mg/kg body weight) $30 \mathrm{~min}$ before and $30 \mathrm{~min}$ after the alkylating agents.

\section{Acknowledgements}

Research supported by the Universidade Luterana do Brasil (ULBRA) and CNPq.

\section{References}

Ayres M, Ayres-Jr M, Ayres DL and Santos AS (2000) BioStat 2.0, Sociedade Civil Mamirauá/MCT-CNPq, Brasília, 259 pp.

Bacq ZM, Herve A, Leconte J, Fischer P, Blavier J, Dechamps G, Lebihan $\mathrm{H}$ and Rayet P (1951) Protection contre le rayonnement $\mathrm{x}$ par la $\beta$-mercaptoéthylamine. Archs Int Physiol 59:442-447.

Barendsen GW (1964) Modification of radiation damage by fractionation of the dose, anoxia and chemical protectors in relation to LET. Ann New York Acad Sci 114:96-114.

Brookes P (1990) The early history of the biological alkylating agents. Mutation Research 233:3-14.

Delrez M and Firket H (1968) Action paradoxale d'un radioproteteur sur la mitose e les chromosomes in vitro. Biochem Pharmacol 17:1893-1899.

De Souza CA, Santini G, Marino G, Nati S, Congiu AM, Vigorito AC and Damasio E (2000) Amifostine (WR-2721), a cytoprotective agent during high-dose cyclophosphamide treatment of non-Hodgkin's lymphomas: A phase II study. Braz J Med Biol Res 33:791-798.

Eker P and Pihl A (1964) Studies of the growth-inhibiting and radio-protective effect of cystamine, cysteamine and AET on 
mammalian cells in tissue culture. Radiation Research 21:165-179.

Firket RG and Mathieu P (1966) Irradiation et protection de cultures synchrones de cellules Hela. Int J Radiat Biol 2:245253.

Foster-Nora JA and Siden R (1997) Amifostine for protection from antineoplastic drug toxicity. Am J Health-Syst Pharm 54:787-800.

Heddle JA (1973) A rapid in vivo test for chromosomal damage. Mutation Research 18:187-190.

Honjo I, Tchoe YT, Takamori Y and Akaboshi M (1963) Chemical protection for the incorporation of phosphorus-32 into nucleic acids of lymphatic cells against $\gamma$-irradiation. Nature 197:914-915.

List AF, Heaton R, Glinsmann-Gibson B and Capizzi RL (1996) Amifostine protects primitive hematopoietic progenitors against chemotherapy cytotoxicity. Semin Oncol 23:23-34.

Marzatico F, Porta C, Moroni M, Bertorelli L, Borasio E, Finotti $\mathrm{N}$, Pansarasa $\mathrm{O}$ and Castagna L (2000) In vitro antioxidant properties of amifostine (WR-2721, Ethyol). Cancer Chemother Pharmacol 45:172-176.

Mazur L (1995) Induction of micronucleated erythrocytes by MEA, AET, WR-2721 and X-rays. Mutation Research 334:317-322.

Mazur L and Blawat A (1999) Effects of GSH and WR-2721 on induction of micronuclei by cyclophosphamide. Mutation Research 110:67-72.

McCauley DL (1997) Amifostine: A novel cytoprotective agent. Cancer Pract 5:189-191.

Moore MJ (1991) Clinical pharmacokinetics of cyclophosphamide. Clin Pharmacokinet 20:194-208.

Murray D, Rosenberg E and Allalunis-Turner MJ (2000) Protection of human tumor cells of differing radiosensitivity by WR-1065. Radiat Res 154:159-162.

Santini V and Giles FJ (1999) The potential of amifostine: From cytoprotectant to therapeutic agent. Haematologica 84:1035-1042.

Santos-Mello R (1977) Linfócitos e radiações: I- Efeitos da cisteamina e dimetilsulfóxido. II- Aberrações cromossômicas e sobrevivência de linfócitos. PhD Thesis, Universidade Federal do Rio Grande do Sul, Porto Alegre.

Schmid W (1975) The micronucleus test. Mutation Research 31:9-15.

Schuchter LM (1997) Current role of protective agents in cancer treatment. Oncology 11:505-516.

Shaw LM, Bonner H and Lieberman R (1996) Pharmacokinetic profile of amifostine. Semin Oncol 23:18-22.

Siegel S (1956) Nonparametric Statistics for the Behavioral Sciences. Mc Graw-Hill, New York, 350 pp.

Sinclair WK (1967) X-ray survival and DNA synthesis in Chinese hamster cells. Proc Natl Acad Sci US 58:115-122.

Sinclair WK (1968) Cysteamine: Differential X-rays protective effect on Chinese hamster cells during the cell cycle. Science 159:442-444.

Spencer CM and Goa KL (1995) Amifostine. A review of its pharmacodynamic and pharmacokinetics properties, and therapeutic potential as a radioprotector and cytotoxic chemoprotector. Drugs 50:1001-1031.

Takagy Y, Shikita A, Terasima T and Akaboshi S (1974) Specificity of radioprotective and cytotoxic effects of cysteamine in Hela $\mathrm{S}_{3}$ cells: Generation of peroxide as the mechanism of paradoxical toxicity. Radiation Research 60:292-301.

Valeriote F and Tolen S (1982) Protection and potentiation of nitrogen mustard cytotoxicity by WR-2721. Cancer Res 42:4330-4331.

Vergroesen AJ, Budke L and Vos O (1967) Protection against $\mathrm{X}$-irradiation by sulphydryl compounds. Int J Radiat Biol 13:77-92.

Vos O and Kaalen AC (1968) Protection against ionizing radiation at the cellular level, assessed by various parameters. Int J Radiat Biol 14:107-118.

Vos O, Grant GA and Budke L (1969) Radiation protection by disulphides in tissue culture. In: Moronson HL and Quintiliani L (eds) Radiation Protection and Sensitization, Proceedings of the Second International Symposium on Radiosensitizing and Radioprotective Drugs, Rome, p 211.

Yang SJ and Hahn GM (1968) Cell-cycle-dependent protection by cysteamine against X-ray-induced chromosome aberrations. Int J Radiat Biol 14:71-73.

Associate Editor: Catarina S. Takahashi 